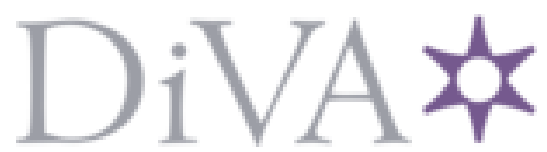

http://www.diva-portal.org

\title{
Postprint
}

This is the accepted version of a paper published in Literature and medicine. This paper has been peer-reviewed but does not include the final publisher proof-corrections or journal pagination.

Citation for the original published paper (version of record):

Åström, B. (2015)

A Narrative of Fear: Advice to Mothers

Literature and medicine, 33(1): 113-131

https://doi.org/10.1353/lm.2015.0001

Access to the published version may require subscription.

N.B. When citing this work, cite the original published paper.

Permanent link to this version:

http://urn.kb.se/resolve?urn=urn:nbn:se:umu:diva-106619 


\section{A Narrative of Fear: Advice to Mothers}

In 2009, the UK newspaper The Daily Mail published an article with the headline "Killed by a kiss: anguish of a mother who lost her newborn baby after passing on cold sore infection." In the article it is described how the mother "was putting the baby's life at risk" and how the infant dies after having contracted the herpes simplex virus "from her mother's lips." ${ }^{1}$ The article uses highly emotive language to suggest that any baby is at risk from its mother, who, may cause "cerebral palsy, blindness and seizures," as well as kill the child. The language of the article in The Daily Mail echoes that employed by the Victorian physician William Carpenter, who in a medical advice book aimed at mothers, relates how a woman, by breastfeeding her child while agitated, has "sealed its fate": the child dies immediately after feeding. ${ }^{2}$ In both texts the mothers are described as having killed their children, albeit unintentionally, through their ignorance. In both cases, the writers are drawing on a regulative discourse I term narrative of fear, which suggests to mothers that their skills and knowledge are insufficient, that they are inadequate as carers and likely to kill their children, or at least damage them for life. Christina Hardyment, writing on UK present-day advice literature, has noted that "Guilt is the hallmark of the age,"3 but guilt was also present in Victorian advice literature, which constructed mothering as a difficult activity fraught with danger. In this article I show how the present-day prescriptive texts, rather than articulating a new phenomenon, perpetuate a regulative discourse developed in the nineteenth century. The claim, often made, that present-day mothers are subject to greater pressures than ever before is not borne out by the textual evidence.

It seems a commonplace that mothering is becoming "more intensive in advanced industrial societies," that the demands placed on present-day mothers are greater than those encountered by mothers in previous periods. ${ }^{4}$ Sharon Hays, for example, argues for a rise in 
the twentieth century of "intense mothering," which requires mothers to "expend a tremendous amount of time, energy, and money in raising their children." 5 This intense mothering has, in turn, according to Susan Douglas and Meredith Michaels, led to "new momism." New momism, they explain, is a "set of ideals, norms and practices" which, while appearing to valorize motherhood, also places impossible demands on women. ${ }^{6} \mathrm{New}$ momism and intense mothering demand that mothers at all times place their children's needs and desires before their own. ${ }^{7}$ However, as other scholars have noted, there was an expectation also in earlier periods that women devote their entire existence to their children. Barbara Ehrenreich and Deirdre English, for example, point out that in the early twentieth century, US women were supposed to make their children the "center of life." ${ }^{8}$ Similarly, Lisa Smyth, focusing on the UK, has noted how mothers, throughout the twentieth century, have been subjected to "a range of often competing norms" for childcare, which all have placed great demands on them. ${ }^{9}$ In 1957, Donald Winnicott, for example, demanded that the mother must take pleasure in every aspect of childcare, including getting soaked in the child's urine: "The mother's pleasure has to be there, or the whole procedure is...useless."10

Expressed in tandem with the notion of maternal self-sacrifice, from the nineteenth century onwards, is the idea that the mother is responsible for every aspect of the child's physical, emotional and mental wellbeing, and that while she is important, she is also dangerous, and liable to destroy the child, if not closely supervised. It is claimed that it only takes one mistake to destroy a child. When Jody Kantor, in an article in the New York Times on dietary requirements for children, describes one single hot dog as the gateway to a lifetime of unhealthy eating, what Rebecca Kukla terms "the single corrupting bite," she is following in the tradition of, for example Thomas Bull. ${ }^{11}$ In 1837 he warns that a pregnant woman must follow all the restrictions placed on her by her doctor, since "by one act of disobedience she may blast every hope of success" and lose the child. ${ }^{12}$ Like Kantor's twenty-first century 
mother, who lets her guard down and allows the child one hot dog, thus ruining years of careful monitoring of its diet, Bull's prospective mother "throw[s] away, in a single moment, the result of hours, nay of days and weeks, of careful and persevering deprivation" and kills her unborn child. ${ }^{13}$ Pregnancy and mothering are presented by both Kantor and Bull as a constant struggle, where one momentary lapse of concentration will destroy the child. In both periods, the texts play on feelings of guilt and inadequacy, creating a climate of fear.

After a brief overview of the prescriptive nature of advice literature past and present, this article will provide a context for the development of the regulative discourse in the nineteenth century, before discussing two of its features: the insistence on the mother's total immersion in the child's care, and the notion that the mother is solely to blame for any physical or emotional problems the child might develop. Material from the US and the UK will be analyzed, since there has been an interchange: the books published in the UK in the nineteenth century were widely read in the US, and, later on, authors such as Benjamin Spock and T. Berry Brazelton have been influential in the UK. The main focus is on the nineteenth century and on the present day, juxtaposing texts to show the resonances in the language, but in order to show the continuity of the narrative of fear, there are also brief references to twentieth-century material.

It should be noted, however, that what is discussed in this article is the ideas expressed in the texts, not actual mothering practices, nor mothers' acceptance of, or resistance to, the advice given.

\section{Advice books}

In a study of present-day, UK, motherhood, Rachel Thomson et al. view the proliferation of advice to mothers as a regulatory discourse that produces "new and creative forms of surveillance and control."14 The forms which the advice takes, including websites such as 
Mumsnet, blogs, magazines and online journals, may indeed be new, but the language in which this regulatory discourse is expressed goes much further back.

In a survey of twentieth century advice books read in the UK, from Frederick Truby King, Donald Winnicott and John Bowlby, to Benjamin Spock, Penelope Leach and Gina Ford, Angela Davis has noted the wide discrepancy in the advice given, for example moving from the insistence on strict routines to advocating a more baby-centered approach and back to routines again. Yet, she notes, the advice is always presented in a "consistently prescriptive manner" and the experts stress "the extreme consequences" that would be the result if the advice is not taken. ${ }^{15}$ Donald Winnicott, for example, states that mothers who are not devoted enough are "one factor in the aetiology of autism." 16 The standards set for mothers during this period are, as Davis notes, "unattainably high," meaning that most readers are unable to conform to them, which may cause anxiety and guilt. ${ }^{17}$

The advice literature published in the nineteenth century also plays on feelings of anxiety, pointing out that the life of a baby was "literally a mere cobweb of strength." 18 Infant mortality remained high throughout most of the nineteenth century and middle-class mothers were generally blamed as the cause. ${ }^{19}$ The advice books were initially published by "pious mothers" and clergymen, dealing mainly with issues of morality and a religious upbringing, but as the century progressed, more and more medical men came to publish advice literature. ${ }^{20}$ As Patricia Branca has pointed out, the books "capitaliz[ed] on new anxieties" but could offer "very little in the way of constructive advice," since medical science was advancing slowly. ${ }^{21}$ Thus, the advice literature pointed out all the dangers that beset the infant and its mother, but could not show how to avoid them.

The nineteenth-century advice books were a departure from those of earlier periods in that they addressed a new group of readers, middle-class mothers, but also in their focus on the emotional side of childcare. The books written during the seventeenth century, by medical 
men such as Jacques Guillemeau, as well as mid-wives such as Jane Sharpe, or women writing for relatives, such as Elizabeth Clinton, Duchess of Lincoln, whilst employing a prescriptive tone promising disaster if the advice was not followed, focused solely on practicalities such as breastfeeding and weaning, suitable clothing and so forth. ${ }^{22}$ The nineteenth-century writers, on the other hand, discuss at length how the women's emotions will affect the fetus and the nursing child, noting that a fit of anger will cause spontaneous abortion $^{23}$ or turn the breastmilk into such poison that the child will die. ${ }^{24}$ The mothers are instructed that everything they do will have a direct effect on the child, both in the present and in adulthood, and so the burden on them to get everything absolutely right is enormous, a burden that has remained a constant feature ever since.

\section{Developing a narrative of fear}

Although it would be impossible to pinpoint one particular cause for the development of the regulative discourse, I will attempt in this section to create a context by teasing out some strands of influence: women's removal from the workforce, a tension over parental influence, and the medicalization of childcare.

\section{From worker to mother}

As noted by scholars such as Lenore Davidoff and Catherine Hall, the concept of motherhood began to change from the middle of the eighteenth century. ${ }^{25}$ Factors driving this redefinition include, as Eileen Yeo notes, nation-building, the rise of the middle-class and the professionalization of medicine. ${ }^{26}$ A large population was seen as imperative for the creation or maintenance of the nation and Yeo points to a shift in the societal attitude towards women, from a focus on the obedient wife to the mother. ${ }^{27}$ Hilary Marland notes that producing children was regarded as women's "paramount duty and most rewarding purpose in life." 28 
Giving birth to healthy children also became a class issue with the emergence of the middleclasses. Increasingly there was a concern that the women were "failing to fulfil their reproductive duties," giving birth to sickly children, whereas the working classes produced large amounts of healthy, viable children. ${ }^{29}$ It is a recurring notion in many of the advice books, as well as other texts of the period, that middle-class women were wilfully "shirking" their obligations as breeders. ${ }^{30}$ There was a general sense of crisis and the regulative discourse developed partly as a measure to solve that crisis, much in the same way as twenty-first discourse on parenting has developed in response to a perceived societal crisis. ${ }^{31}$

In their respective works Sharon Hays, Diane Eyer, and Susan Douglas and Meredith Michaels argue that the present-day US discourse of intense mothering and new momism is an attempt at keeping women out of the workplace. Similarly, it has been claimed that John Bowlby's stress on women remaining in the home to avoid what he termed "maternal deprivation" was linked to a UK government policy of removing women from the work force after the Second World War. ${ }^{32}$ However, as scholars such as Davidoff ${ }^{33}$ and Gorham ${ }^{34}$ have shown, the cult of domesticity in the nineteenth century entailed a new ideal that middle-class women should no longer be part of the workforce. The ideal of domesticity had been in circulation earlier, ${ }^{35}$ but became "codified and culturally dominant during the long eighteenth century." ${ }^{36}$ Work was increasingly seen as a major part of the middle-class husband's identity; he was the breadwinner whose task it was to provide for the family. ${ }^{37}$ The world of business was also a place of contamination ${ }^{38}$ and women must be protected "from the taint of market forces which would have weakened paternalistic authority." ${ }^{39}$ Although the "separate spheres" were not quite as separate as has been suggested, ${ }^{40}$ the middle-class woman was still not expected to support the family financially. Instead the task of the wife was to contribute to the social success of the family, raising or maintaining the status of the family by being genteel, by performing no manual labor, and as the century progressed, no housework. ${ }^{41}$ Since women 
were increasingly regarded as "more moral, more pure (and more clean) than men," they were also increasingly regarded as ideally suited to childrearing. ${ }^{42}$ Motherhood gained in status, and the middle-class mothers were assumed to possess a "moral authority." 43 Women were thus "encouraged to exhibit an unprecedented amount of concern with the child-rearing process," "to devote time and effort" to the role of mother, but also to approach mothering as "a skill that had be learned," preferably from the proliferation of advice books offered. ${ }^{44}$ These ideas are reflected in present-day intensive mothering, which is also a child-centered activity requiring a "tremendous amount of time [and] energy," 45 a "set of skills to be honed and perfected," as well as also something that should be "guided by experts," as Charlotte Faircloth has shown in her interviews with British and French mothers. ${ }^{46}$

\section{Competition with fathers}

That many present-day fathers feel excluded from the family is exemplified by, for instance, fathers' rights activism, such as Fathers4Justice and Families Need Fathers, in the UK. Men appear to be increasingly questioning what is perceived as a gender bias in the awarding of custody after divorce, as well as the way courts have tended to support women's right to prevent fathers from having any contact with their children. ${ }^{47} \mathrm{UK}$ law states that an unmarried father only has legal rights to his child if he is named on the birth certificate and websites such as Law \& Parents are full of requests for help from estranged fathers who are not allowed access to their own children. ${ }^{48}$ These public expressions of a feeling of exclusion may be the result of a process that, as Lenore Davidoff has described, began in the nineteenth century, with a change in the way society and the law regarded parents' rights and relations to the children. ${ }^{49}$ In previous centuries, fathers were assumed to have absolute authority over the family, but this began to change "as women, children and other dependents found new ways 
to resist or bypass them." ${ }^{50}$ Indeed, as John Tosh has demonstrated, the father's absolute authority in the household was under threat, both symbolically and in practice. ${ }^{51}$

As the nineteenth century progressed, mothers came increasingly to be seen as more suited to the raising of children and so the fathers' "significance as parents was correspondingly diminished." 52 For example, Elizabeth Sandford wrote in 1839 that for the growing child, the mother "is the best guardian and instructress" and Sarah Ellis stated in 1843 that fathers lacked "the nicety and tact to manage the minute affairs of domestic life, and especially those of individual feeling." ${ }^{, 53}$ Both authors imply that fathers lack the right qualities for their children's education and emotional growth. In general, "the moral gap between husband and wife was widely acknowledged," leading to the notion that since women were morally superior, they should be the ones in charge of the children. ${ }^{54}$

Thus the nineteenth century witnesses a conflict in the triad of father-mother-child, where mothers are expected to take over both the physical, moral and emotional upbringing of the children. Fathers, demanding not only obedience but love and affection from their children, as Gorham and Davidoff and Hall have demonstrated, ${ }^{55}$ but often physically separated from them through the constraints of work, ${ }^{56}$ find themselves competing with mothers who have access to "a whole range of material and emotional opportunities which men were increasingly denied, whether by choice or by circumstances." ${ }^{, 57}$ The relationship between child, mother and father seems to have been open to a number of competing loyalties, leading to potential tensions. Perhaps within these tensions can be discerned some of the reasons for the narrative of fear. The double message to women that they are solely responsible for taking care of the children but at the same time a potential danger to them could be viewed as a patriarchal response to a feeling of exclusion.

\section{The rise of the doctor}


Towards the end of the nineteenth century mothering became increasingly medicalized. In the US in particular, an idea took hold that just being a mother was not enough to make one fit to raise a child. The intensely sentimentalized view of mothers that had prevailed before was replaced by a demonization, and was later followed by a declaration of the mother as incompetent in rearing her own children. ${ }^{58}$ Similarly, at the beginning of the twentieth century, UK mothers were on the one hand told that mothering was a skill any woman could easily attain, ${ }^{59}$ whilst they at the same time were blamed for not doing it correctly; any physical or mental problems encountered by their children were "attributed to inadequate mothering."

The process of discrediting women in general and mothers in particular began much earlier, however. It can be traced back at least as far as to the man midwife making his way into the early modern birthing room. ${ }^{61}$ Early modern advice books often reject what is presented as the ill-advised habits of mid-wives, female relatives and neighbors in terms of infant feeding, clothing and treatment of illnesses ${ }^{62}$ and this continues into the eighteenth century, for example in William Cadogan's 1757 text, which is intended “to convince most Nurses, Aunts, Grandmothers, \&c. how much they have hitherto been in the wrong, what mischief is done to Children, and what multitudes are destroyed or spoiled." ${ }^{\prime 63}$ Doctors go to great lengths to convince prospective mothers that they are in no way equipped to deal with their own pregnancies, that other women do not possess the correct knowledge either, and that only a trained physician can make sure that their children survive.

In the nineteenth century, medical doctors increasingly were referred to "on all issues of mental and physical health" and they were advised to focus on married women as a secure source of income. ${ }^{64}$ Towards the middle of the nineteenth century most women contacted a doctor as soon as they suspected pregnancy ${ }^{65}$ and women who could afford it had their children delivered by men. ${ }^{66}$ The women were becoming increasingly dependent on the 
doctors' advice, and the notion of the doctor as the only hope is present in the advice books published. Infant mortality was indeed high, but as Patricia Branca has pointed out, in many cases the doctors could not provide much help beyond general advice. ${ }^{67}$ Yet, despite such limitations, Thomas Graham presses upon his readers that they must "assist the endeavours of [the] physician" and not follow the advice of nurses, who "love to display their own influence, and even boast if they can cheat the doctor." ${ }^{68}$ Indeed "no lying-in woman can neglect the principal directions of her physician but at the risk of her health, perhaps her life." 69 Graham's text demonstrates the attempts at establishing authority over the pregnant woman, and the struggle with the nurse, who is not medically qualified to deal with such difficult matters. Although the mother-reader addressed in the texts is constructed as eager to do the right thing, but in need of professional help and assistance, case stories often refer to the foolish and rash mother who will "give way to the first fancy that flits across her mind, or the first random advice that is offered her." ${ }^{, 70}$ Pregnancy and childbirth are presented as complicated procedures that cannot be understood by such women. To try to cope without a physician is to gamble, not only with the child's life, but also the mother's. In short, not only can the mother not be trusted to know herself what is best for her or her child, she should likewise not trust the "random advice" of other laypeople. Instead it is paramount that she follows the advice of her doctor.

A case in point is nursing. Although all medical advice during this period insists that women should breastfeed their own children, the doctors acknowledge that sometimes a wet nurse has to be employed. Since the feeding of the child is so important, the choice of wet nurse is one that must be considered very carefully, and thus must be made at least in consultation with a physician. ${ }^{71}$ Andrew Combe even argues that the choice of wet nurse must have the "sanction" of a doctor, who will examine her thoroughly and make sure that she is healthy. ${ }^{72}$ As with so many other aspects of mothering and childrearing, the writing suggests 
that it is a question of life or death - choosing the wrong wet nurse may kill the child. Graham relates an instance where an unsuspecting family hires a syphilitic nurse, who then proceeds to infect the infant, and, through the child, the father, the mother, three other children, a maid servant and two clerks. Graham firmly locates the blame for this tragedy with the family who did not "inquir[e] into her character" and suggests that this tragedy could have been avoided if they had only consulted a doctor. ${ }^{73}$ Thus doctors press home, again and again, that it is not safe to make any health-related decisions without the aid of a doctor.

I suggest then, that a combination of financial, emotional and cultural factors combined to create a narrative of fear, the effect of which was, as Branca notes, to make the "Victorian woman seriously questio[n] her capabilities to fulfill her most natural of functions motherhood."74 Through the language of the advice books she was given the impression that through her very existence, she posed a threat to the health of both her child and herself.

\section{Regulating mothers}

\section{Full-time mothering}

A component of the narrative of fear is the notion that the mother should always be at the child's beck and call and that she must receive all the fulfillment and enjoyment she requires through the care of her child. The UK child expert Penelope Leach, for example, stresses that all child care should be dictated by the child's needs rather than the mother's. ${ }^{75}$ Indeed, there should be no conflict between the needs of the mother and those of the child, since a mother

should derive all necessary fulfilment from "being so much enjoyed and needed." $" 76$ This focus on the child's needs is often taken as an argument for mothers not working, as when the US doctor T. Berry Brazelton suggests that a "woman's most important role is being at home to mother her small children": women should see "mothering as a goal that is as important as anything they can achieve in the professional life."77 If the mother should not stay at home to 
bond with the child during the first year, it will at best become an academic failure, but more probably a criminal or a terrorist, according to Brazelton. ${ }^{78} \mathrm{~A}$ woman should not need to seek confirmation, stimulation or validation from any other source than that of her child. If she does, her child will suffer.

This stress on the requirement for mothers to "interpret their child's every demand as an urgent and legitimate need"79 is present in the twentieth century as well, when Benjamin Spock states that mothers have to be able to anticipate every need the baby might have before it arises ${ }^{80}$ Similarly, John Bowlby warns against "maternal deprivation," which would occur not only if the child is permanently separated from the mother, but also if she is "unable to give him the loving care small children need." ${ }^{81}$ In the same way the nineteenth-century mother must know her child's "every cry and what it meant" and act accordingly. ${ }^{82}$

Elizabeth Badinter has suggested that for present-day mothers "pregnancy signals the end of pleasure, freedom, and the carefree life of non-mothers" and that "the future mother no longer belongs to herself." ${ }^{83}$ Such attitudes were also present in the language employed by nineteenth-century authors, particularly in their attempts at persuading women to breastfeed. In the texts there is an assumption that any reluctance to nurse stems from a selfish desire for amusement outside the home, but, as Pye Henry Chavasse states, the new mother "must make up her mind to forego the so-called pleasures of fashionable life." ${ }^{84}$ For her there will be no "frequenting of balls, of routs, or of parties: a nursing-mother has no business to be at such places"; instead she should "devote herself to her infant and to her household, and she will then experience the greatest happiness this world can afford!" 85 Thus a mother who desires to leave the house and converse with other adults is made to feel that she is selfish and vain. Indeed, not placing the child first may even cause it to "sicken, pine and die." mothering produces "the greatest happiness" possible is echoed in the present day in the notion that "mothering is now understood to be a vehicle to personal fulfilment for women" 
that Charlotte Faircloth has noticed in her interviews with women attached to La Leche League in the UK and France. ${ }^{87}$

The ban on suspect enjoyment for nineteenth-century mothers includes activities in the home as well. Andrew Combe prohibits "endless novel-reading" 88 and, according to Thomas Bull, a mother should "make up her mind exclusively to devote herself to the duties of a nurse, and give up all engagement that would interfere with health." ${ }^{\circ 9}$ For these authors, there is no excuse for a woman to leave the home - apart from exercise for the child's benefit - or to engage in any activity that is not child centered. Books should not be read for enjoyment but for edification, and any activity undertaken should be for the good of the child or not undertaken at all.

It is taken as self-evident that breastfeeding is an emotionally fulfilling activity, and that no good mother would voluntarily choose to abstain from this "delightful duty" that "no earthly pleasure of the fond mother can equal." 90 The apparent paradox that some women wish to abstain from such "earthly pleasure" is never addressed. This discourse is very similar to that of present-day advocates of breastfeeding, such as La Leche League, and proponents of attachment parenting, such as Dr. William Sears. In both instances, it is stressed that breastfeeding, so-called baby wearing and co-sleeping are wonderful experiences that will bring parents and children together in a close bond, and any perceived difficulties have simply to be borne patiently. Not feeling this way is to not care about the child enough, and to be a selfish mother, which in turn may damage the child's emotional development. ${ }^{91}$

There are, of course, other voices that state that it is perfectly permissible for women to not undertake full-time mothering and, for example, work outside the home. The UK website Mental Healthy, for instance, suggests that the way to avoid the "danger of depression for 'Super Mum," that is, the working mother who tries to "do it all," is by "simply admitting" that this is not possible and instead letting "some things slide." 92 In short, women are warned 
that although it is perfectly permissible to work, it may cause depression. Should this happen, however, all they need to do is "simply" admit their shortcomings and let things slide. What starts out as a reassuring message becomes yet another demand on already frustrated women.

\section{Always at fault}

Part of the present-day narrative of fear is the notion that mothers alone are responsible for every aspect of their children's physical and mental development. ${ }^{93}$ But this responsibility does not begin at the birth of the child. Prospective mothers must make sure that they lead a healthy lifestyle. As The Daily Mail points out, expectant mothers "could condemn their offspring to a lifetime of obesity" and mothers who take antidepressants during pregnancy are warned that they may expose their children to a condition, which although very rare, "can lead to heart failure." $" 94$ On the other hand, as The Guardian states, maternal stress during pregnancy may reduce IQ-levels by up to ten points and cause attention deficit problems ${ }^{95}$ and depression during pregnancy may cause lower muscle tone and elevated stress responses in new-born children, ${ }^{96}$ suggesting that leaving emotional problems untreated is not a viable option. In these texts, the women are told that it is their fault that the children suffer. Their indulgence, or over-anxiety ruin the children's health, "condemn" them to a lifetime of suffering, or stunt their intellectual growth. Nineteenth-century women were told the same thing, but their children might suffer even worse effects. As Patricia Branca notes, motherly "mis-management of the child" was assumed to be the cause for the high infant mortality. ${ }^{97}$ This mismanagement also extended to the mother's own emotional control. Combe maintains that the way a child develops is "a legible transcript of the mother's condition and feelings during pregnancy."98 Thus a mother's shortcomings, or "guilt" as Combe calls it, are writ large on her child, for the world to see. ${ }^{99}$ Mothers who fail to conduct themselves properly during the pregnancy, who become nervous, agitated, angry or scared will give birth to 
nervous, sickly and deformed children, possibly with "convulsive or epileptic disease."100 Other authors maintain that a mother's unchecked emotions can actually cause miscarriages. ${ }^{101}$ In short, if a woman does not stay calm and serene at all times, she is likely to cripple or kill her child.

Having given birth does not mean that the twenty-first-century mother can relax the policing of her emotions. A recurring question on online discussion fora for mothers is whether stress hormones may be passed on to the nursing infant and what effects that might have. Research seems to suggest that the stress hormone cortisol transfers through breastmilk, and may result in heightened fear responses in infants. ${ }^{102}$ Nineteenth-century doctors also argued that strong emotions such as grief, anxiety or fear have a direct effect on the milk, but the consequences are much more serious. As C. H. F. Routh writes in the Lancet, it is a wellknown fact that children who are nursed by mothers who have been upset will suffer "diarrhoea, convulsions, atrophy, and even death." ${ }^{.103}$ Indeed, all the authors surveyed in this article agree that strong emotions, including "sudden joy," will cause the children acute suffering and pain, if not death. ${ }^{104}$ The emphasis on the control of emotions in these texts is striking. Again and again the authors stress how important it is for the mothers to keep themselves and their emotions in check. If they do not, their children will suffer stomach upsets, fever or worse. The mother is to remain calm and serene at all times. To persuade her to do that, the authors relate a number of cautionary tales underscoring how dangerous her mind can be to the infant. One such tale, first published by Dr von Ammon in his book Die ersten Mutterpflichten und die erste Kindespflege, later repeated by Andrew Combe and Thomas Graham as well as William Carpenter, is that of a woman who nurses her child after having been involved in a knife fight. As Carpenter points out, by nursing her child, she has "sealed its fate": after feeding the child "sank dead upon its mother's bosom." 105 The implication is clear - by breastfeeding whilst agitated, the woman has killed her own child. 
But Carpenter is not satisfied with just one cautionary tale. He continues with two more, which should "serve as a salutary warning to mothers, not to indulge in the exciting or depressing passions." ${ }^{106}$ In the one, the mother is thinking of a close friend, whose child has died from hydrocephaly; in the other, a mother who has lost several of her children to what seems a congenital disease worries that her new infant, although seemingly healthy, might also die. In both cases the children die shortly after having been breastfed. It is noteworthy that Carpenter uses the term "indulge" in reference to these passions, as if the women are choosing to wallow in unsuitable emotions, on a par with Combe's "endless novel reading." Rather than expressing sympathy for the woman who has lost several children, he chides her for worrying about the one she has left, and bluntly states that through this worrying she causes its death. By indulging in dangerous emotions, Carpenter claims, these women kill their children.

Carpenter devotes perhaps more space than any other author to discussions of the damaging effects emotions will have on the fetus and the infant, but all the authors discussed here bring them up. The repeated admonitions that mothers must refrain from becoming upset seem almost obsessive. What is lacking, however, is any advice for the mothers as to how to achieve this calm, or a suggestion that help might be had. The burden lies solely on the mother, to remain composed at all costs, no matter what she is subjected to. If she lets herself become upset, the fault is hers, as in Carpenter's narrative of the wife of a drunken and brutal husband. ${ }^{107}$ Her fear of him causes the milk to go bad and the infant suffers from indigestion. The problem, as Carpenter presents it, is the wife's inability to control her emotions, rather than the husband's violent behavior. To the authors of the advice books, the mother must accept her situation with equanimity, no matter what difficulties she might face, and never complain, regardless of how difficult her situation might become. 
Present-day texts, even though they also suggest that women's emotions, in the form of hormones in the bloodstream, can cause problems for their children, do at least in some cases suggest that the pregnant women should be given help and support by partners, friends and relations. ${ }^{108}$ The present-day mother is not left quite as alone as the nineteenth-century one.

\section{Conclusion}

As Rebecca Kukla has noted, mothering is a "test one can never pass but is always at risk of failing." 109 Much of present-day advice given to mothers echoes that of the nineteenth-century authors: a mother must give up all thoughts of herself and devote all her time and energy to the child, and everything, from minor setbacks to major illnesses are her fault. ${ }^{110}$ If she does not do everything exactly right, the child will suffer. The difference is that the present-day child runs the risk of obesity, depression, reduced IQ and similar ailments, whereas the nineteenth-century child might die. The fact that infant mortality has been greatly reduced has not lead to a reduction in the blame of mothers. The stories told are the same, attempting to make sure that mothers are kept under control. Yet, the sheer number of competing channels for advice, which Thomson et al. view as a potential problem, may also afford pregnant women and new mothers more sites and greater opportunities to resist the narrative of fear.

\section{Bibliography}

Apple, Rima D. Mothers and Medicine: A Social History of Infant Feeding. London: The University of Wisconsin Press, 1987.

Apple, Rima D. Perfect Motherhood: Science and Childrearing in America. New Brunswick: Rutgers University Press, 2006. 
Badinter, Elizabeth. The Conflict: How Modern Motherhood Undermines the Status of Women. New York: Metropolitan Books, 2011.

Beeton, Isabella. Beeton's Book of Household Management. 1861. London: Jonathan Cape, 1968.

Bowlby, John. Child Care and the Growth of Love. 1953. Harmondsworth: Penguin Books, 1965.

Buchan, William. Advice to Mothers, on the Subject of Their Own Health; and of the Means of Promoting the Health, Strength, and Beauty of Their Offspring. Boston, 1809.

Bull, Thomas. Hints to Mothers for the Management of Health During the Pregnancy and in the Lying-in Room. 1837. $16^{\text {th }}$ edition. London, 1865.

Cadogan, William. An Essay Upon Nursing and the Management of Children from their Birth to Three Years of Age. London, 1757.

Carpenter, William. Principles of Human Physiology $3^{\text {rd }}$ ed. London, 1846.

Chavasse, Pye Henry. Advice to a Wife on the Management of Her Own Health. $7^{\text {th }}$ ed. London, 1866.

Combe, Andrew. The Management of Infancy. 1840. $9^{\text {th }}$ edition. Edinburgh, 1860.

Davidoff, Leonore and Catherine Hall. Family Fortunes: Men and Women of the English Middle Class 1750-1850. London: Routledge, 1994.

Davidoff, Leonore and Megan Doolittle, Janet Fink, Katherine Holden. The Family Story: Blood, Contract and Intimacy, 1830-1960. Harlow: Longman, 1999.

Davidoff, Leonore. Worlds Between: Historical Perspectives on Gender \& Class. Cambridge: Polity Press, 1995.

Doane, Janice and Devon Hodges. From Klein to Kristeva: Psychoanalytic Feminism and the Search for the "Good Enough" Mother. Ann Arbor: The University of Michigan Press, 1992. 
Douglas, Susan J., and Meredith W. Michaels. The Mommy Myth: the Idealization of Motherhood and How It Has Undermined All Women. New York: Free Press, 2005.

Ehrenreich, Barbara and Deirdre English. For Her Own Good: Two Centuries of the Experts' Advice to Women. Westminster: Knopf Publishing Group, 2005.

Eyer, Diane. Motherguilt: How Our Culture Blames Mothers for What's Wrong with Society. New York: Times Books, 1996.

Faircloth, Charlotte. Militant Lactivism?: Attachment Parenting and Intensive Motherhood in the UK and France. New York: Berghahn, 2013.

Families Need Fathers. http://www.fnf.org.uk/ (accessed February 19, 2014.)

Fathers4Justice. http://www.fathers-4-justice.org (accessed February 19, 2014.)

Francus, Marilyn. Monstrous Motherhood: Eighteenth Century-Culture and the Ideology of Domesticity. Baltimore: The Johns Hopkins University Press, 2012.

Glynn, Laura M, Elysia Poggi Davis, Christine Dunkel Schetter, Aleksandra Chicz-DeMet, Calvin J. Hobel and Curt A. Sandman. "Postnatal Maternal Cortisol Levels Predict Temperament in Healthy Breastfed Infants.” Early Human Development 83 no. 10 (2007): 675-681.

Gorham, Deborah. The Victorian Girl and the Feminine Ideal. London: Croom Helm, 1982.

Graham, Thomas J., On the Management and Disorders of Infancy and Childhood. London, 1853.

Guillemeau, Jacques. Nursing of Children. London, 1612.

Hardyment, Christina. Dream Babies: Childcare Advice from John Locke to Gina Ford. London: Frances Lincoln, 2007.

Hays, Sharon. The Cultural Contradictions of Motherhood. New Haven: Yale University Press, 1996. 
Hope, Jenny. “Taking Prozac During Pregnancy Raises Risk of High Blood Pressure in Unborn Children. The Daily Mail Online, January 12, 2012. http://www.dailymail.co.uk/news/article-2085923/Taking-Prozac-pregnancy-raises-riskhigh-blood-pressure-unborn-children.html (accessed February 19, 2014.)

Kantor, Jody. "Memo to Nanny: No Juice Boxes.” New York Times, September 28, 2006 http://www.nytimes.com/2006/09/28/fashion/28nanny.html?_r=0. (accessed February 19, 2014.)

Kukla, Rebecca. "Measuring Mothering." The International Journal of Feminist Approaches to Bioethics 1, no. 1 (2008): 67-90.

La Leche League. http://www.llli.org/ (accessed February 19, 2014.)

Law \& Parents "What are the Legal Rights of a Father?" http://www.lawandparents.co.uk/what-are-legal-rights-father.html (accessed February 19, 2014.)

Lockhart, Liz. "The Dangers of Depression for 'Super Mum.” Mental Healthy. http://www.mentalhealthy.co.uk/news/777-the-dangers-of-depression-for\%E2\%80\%98super-mum\%E2\%80\%99.html (accessed February 19, 2014.)

Macrae, Fiona. "Eating for Two in Pregnancy Can Make your Child Fat by 12: Expectant Mothers Warned They Could Condemn Their Offspring to a Lifetime of Obesity." The Daily Mail Online, October 1, 2013. http://www.dailymail.co.uk/news/article2440851/Eating-pregnancy-make-child-fat-12-Expectant-mothers-warned-condemnoffspring-lifetime-obesity.html (accessed February 19, 2014.)

Markens, Susan, C. H. Browner and Nancy Press. "Feeding the Fetus: On Interrogating the Notion of Maternal-Fetal Conflict.” Feminist Studies 23 no. 2 (1997): 351-372.

Marland, Hilary. Dangerous Motherhood: Insanity and Childbirth in Victorian Britain. Basingstoke: Palgrave Macmillan, 2004. 
Narain, Jaya. "Killed by a Kiss: Anguish of Mother Who Lost Her Newborn Baby after Passing on Cold Sore Infection,” The Daily Mail Online, February 27, 2009. http://www.dailymail.co.uk/news/article-1155973/Killed-kiss-Anguish-mother-lostnewborn-baby-passing-cold-sore-infection.html (accessed February 19, 2014).

Plant, Rebecca Jo. The Transformation of Motherhood in Modern America. Chicago: University of Chicago Press, 2010.

Reynolds, Debbie. "Pregnancy Depression Impacts Stress Hormones of Babies.” Emax. 14 Dec. 2010. http://www.emaxhealth.com/1506/pregnancy-depression-impacts-stresshormones-babies (accessed February 19, 2014.)

Routh, C. H. F. “On the Selection of Wet Nurses from Among Fallen Women.” The Lancet 73 (1859): 580-582.

Ross, Tim. 'Father's Rights Breached by Mother 'Too Upset' to Let Him See Children." The Telegraph, July 25, 2012. http://www.telegraph.co.uk/news/uknews/law-andorder/9424060/Fathers-rights-breached-by-mother-too-upset-to-let-him-seechildren.html (accessed February 19, 2014.)

Shuttleworth, Sally. "Demonic Mothers: Ideologies of Bourgeois Ideal in the Mid-Victorian Era," in Rewriting the Victorians: Theory, History and the Politics of Gender, edited by Linda M. Shires, 31-51.New York and London: Routledge, 1992.

Smyth, Lisa. The Demands of Motherhood: Agents, Roles and Recognition. Basingstoke: Palgrave Macmillan, 2012.

Thomas, Rachel, Mary Jane Kehily, Luch Hadfield and Sue Sharpe. Making Modern Mothers. Bristol: The Policy Press, 2011.

Tosh, John. A Man's Place: Masculinity and the Middle-Class Home in Victorian England. New Haven: Yale University Press, 1999, 2007. 
Wall, Glenda. "Moral Constructions of Motherhood in Breastfeeding Discourse." Gender \& Society 15 no.4 (2001): 592-610.

Ward, Lucy. "Mother's Stress Harms Foetus, Research Shows.” The Guardian, May 31, 2007. http://www.guardian.co.uk/science/2007/may/31/childrensservices.medicineandhealth/p rint (accessed February 19, 2014.)

Wolveridge, James. Speculum Matricis, or, The Expert Midwives Handmaid. London, 1671.

Weatherly, Lionel. The Young Wife's Own Book: A Manual of Personal and Family Hygiene. London, 1882.

Yeo, Eileen. "Constructing and Contesting Motherhood, 1750-1950.” Hecate 31 no. 2 (2005): 4-20.

\footnotetext{
${ }^{1}$ Narain, "Killed by a kiss."

${ }^{2}$ Carpenter, Principles of Human Physiology, 476

${ }^{3}$ Hardyment, Dream Babies, 283.

${ }^{4}$ Smyth, The Demands of Motherhood, 6.

${ }^{5}$ Hays, The Cultural Contradictions of Motherhood, $\mathrm{x}$.

${ }^{6}$ Douglas and Michaels, The Mommy Myth, 4-5 . The original "Momism" was a term coined by Philip Wylie in his book Generation of Vipers in 1945 and referred to suffocating, domineering mothers. For an analysis of the term and how it came to be understood, see Rebecca Jo Plant, Mom: The Transformation of Motherhood in
} Modern America, 2010.

${ }^{7}$ For a discussion of how mothers are expected to subordinate their own needs to that of the child's see, Markens et al, "Feeding the Fetus: On Interrogating the Notion of Maternal-Fetal Conflict."

${ }^{8}$ Erhenreich and English, For Her Own Good, 202.

${ }^{9}$ Smyth, The Demands of Motherhood, 51, 43.

${ }^{10}$ Winnicott, quoted in Doane and Hodge, From Klein to Kristeva, 25.

${ }^{11}$ Kantor, "Memo to Nanny: No Juice Boxes" ; Kukla, "Measuring Mothering," 78-9.

${ }^{12}$ Bull, Hints to Mother, 139. Original emphasis.

${ }^{13}$ Ibid., 139. 
${ }^{14}$ Thomas et al., Making Modern Mothers, 133.

${ }^{15}$ Davis, Modern Motherhood, 137.

${ }^{16}$ Winnicott quoted in Davis 120.

${ }^{17}$ Davis, Modern Motherhood, 137.

${ }^{18}$ Gorham, The Victorian Girl, 67.

${ }^{19}$ Branca, Silent Sisterhood, 99.

${ }^{20}$ Gorham, The Victorian Girl, 66.

${ }^{21}$ Branca, Silent Sisterhood, 76-77.

${ }^{22}$ Author.

${ }^{23}$ Buchan, Advice to Mothers, 12.

${ }^{24}$ Routh, "On the Selection of Wet Nurses," 581.

${ }^{25}$ Davidoff and Hall, Family Fortunes.

${ }^{26}$ Yeo, "The Creation of 'Motherhood," 5.

${ }^{27}$ Ibid., 5 .

${ }^{28}$ Marland, Dangerous Motherhood, 6.

${ }^{29}$ Shuttleworth, "Demonic Mothers,” 32.

${ }^{30}$ Dyhouse Girls Growing Up, 91.

${ }^{31}$ Faircloth, Militant Lactivism, 15.

${ }^{32}$ Davis, Modern Motherhood, 122,112.

${ }^{33}$ Davidoff, World Between, 74.

${ }^{34}$ Gorham, The Victorian Girl, 11.

${ }^{35}$ Davidoff and Hall, Family Fortunes, 155.

${ }^{36}$ Francus, Monstrous Motherhood, 1.

${ }^{37}$ Davidoff, Worlds Between, 106. Dyhouse, Girls Growing Up, 79.

${ }^{38}$ Davidoff, The Family Story, 141.

${ }^{39}$ Davidoff, Worlds Between, 74.

${ }^{40}$ Frankus, Monstrous Motherhood, 3-4.

${ }^{41}$ Gorham, The Victorian Girl, 8, 11.

${ }^{42}$ Davidoff, Worlds Between, 74.

${ }^{43}$ Tosh, A Man's Place, 5. 
${ }^{44}$ Gorham, The Victorian Girl, 65.

${ }^{45}$ Hays, Cultural Contradictions, $\mathrm{x}$

${ }^{46}$ Faircloth, Militant Lactivism, 21, 22, 30.

${ }^{47}$ Ross, "Father's rights breached."

${ }^{48}$ Law and Parents.

${ }^{49}$ Davidoff et al., The Family Story, 142, 145.

${ }^{50}$ Davidoff et al., The Family Story, 136.

${ }^{51}$ Tosh, A Man's Place, 93.

52 Ibid., 47.

${ }^{53}$ Ibid., 91.

${ }^{54}$ Ibid, 44.

${ }^{55}$ Gorham, The Victorian Girl, 38-39, Davidoff and Hall, Family Fortunes, 329-335.

${ }^{56}$ Dyhouse, Girls Growing Up, 4.

${ }^{57}$ Davidoff et al., The Family Story 154.

${ }^{58}$ See, for example, Apple, Mothers and Medicine; Apple, Perfect Motherhood; Doane and Hogdes, From Klein to Kristeva; Plant, Mom: The Transformation of Motherhood.

${ }^{59}$ Davis, Modern Motherhood, 57

${ }^{60}$ Ibid., 113.

${ }^{61}$ Eccles, Obstetrics and Gynaecology in Tudor and Stuart England, 87.

${ }^{62}$ See, for example, Guillemeau, Nursing of Children and Wolveridge, Speculum Matricis, or, The Expert Midwives Handmaid.

${ }^{63}$ Cadogan, An Essay Upon Nursing, 5.

${ }^{64}$ Davidoff and Hall, Family Fortunes 113.

${ }^{65}$ Branca, Silent Sisterhood, 81.

${ }^{66}$ Marland, Dangerous Motherhood, 17

${ }^{67}$ Branca, Silent Sisterhood.

${ }^{68}$ Graham, On the Management of Disorders, 111.

${ }^{69}$ Ibid.

${ }^{70}$ Combe, The Management of Infancy, 102. 
${ }^{71}$ See, for example, Weatherly, The Young Wife's Own Book: A Manual of Personal and Family Hygiene, 87 and Bull, Hints to Mothers, 284.

${ }^{72}$ Combe, The Management of Infancy, 141.

${ }^{73}$ Graham, On the Management and Disorders of Infancy, 191.

${ }^{74}$ Branca, Silent Sisterhood, 76.

${ }^{75}$ Davis, Modern Motherhood, 134.

${ }^{76}$ Eyer, Motherguilt, 5.

${ }^{77}$ Ibid.

${ }^{78}$ Badinter, The Conflict, 48.

${ }^{79}$ Ehrenreich and English, For Her Own Good, xv.

${ }^{80}$ Douglas and Michaels, The Mommy Myth, 18.

${ }^{81}$ Bowlby, Child Care, 14. It is noteworthy that Bowlby also points out the dangers of motherly interest: she may display an "unconsciously rejecting attitude underlying a loving one" or present "an excessive demand for love and reassurance," both of which would be harmful to the child. 14 .

${ }^{82}$ Branca, Silent Sisterhood, 109.

${ }^{83}$ Badinter, The Conflict, 67.

${ }^{84}$ Chavasse, Advice to a Wife, 180.

${ }^{85}$ Ibid., 195.

${ }^{86}$ Bull, Hints to Mothers, 262.

${ }^{87}$ Faircloth, Militant Lactivism, 3.

${ }^{88}$ Combe, The Management of Infancy, 26.

${ }^{89}$ Bull, Hints to Mothers, 261.

${ }^{90}$ Graham, On the Management of and Disorders of Infancy, 125, 161. The only dissenting voice I have found, even amongst books written by mothers rather than doctors, is that of Mrs. Beeton, who refers to the period of breastfeeding as "privation and penance" rather than rapture, and who sees no reason why mothers should not go dancing or to the theatre. She even advocates the use of supplementary food from an early age, so that the mother has the "liberty to go out for business or pleasure." Beeton's Book of Household Management, 1036, 1038-39.

${ }^{91}$ Eyer, Hays, Hardyment and Douglas and Meredith are all very critical towards the prescriptive nature of present-day child care advice and advocate a stance that is more mother-friendly. Yet, they all subscribe to the 
notion that breastfeeding should be carried out, just perhaps not so intensely. The only critic who suggests that mothers should be free not to breastfeed at all is Elizabeth Badinter, who, although her study encompasses many European countries, writes from a French perspective, where breastfeeding is less of a given.

${ }^{92}$ Lockhart, "The Dangers of Depression for 'Super Mum.”"

${ }^{93}$ Douglas and Michaels, The Mommy Myth; Hays, The Cultural Contradiction; Eyer, Motherguilt; Makrens et al., "Feeding the Fetus;" Wall, "Morals Constructions of Motherhood in Breastfeeding Discourse."

${ }^{94}$ Macrae, "Eating for two in pregnancy"; Hope, "Taking Prozac."

${ }^{95}$ Ward, "Mother's Stress."

${ }^{96}$ Reynolds, "Pregnancy Depression."

${ }^{97}$ Branca, Silent Sisterhood, 99

${ }^{98}$ Combe, The Management of Infancy, 22.

${ }^{99}$ Ibid., 22.

${ }^{100}$ Ibid., 19.

${ }^{101}$ Buchan, Advice to Mothers; Graham, On the Management and Disorders of Infancy, 70-71.

${ }^{102}$ Glynn et al, "Postnatal Maternal Cortisol Levels."

${ }^{103}$ Routh, "On the Selection of Wet Nurses," 581.

${ }^{104}$ Chavasse, Advice to a Wife, 192.

${ }^{105}$ Carpenter, Principles of Human Physiology, 476.

${ }^{106}$ Ibid., 477.

${ }^{107}$ Ibid., 476.

${ }^{108}$ Ward, Mother's Stress."

${ }^{109}$ Kukla, "Measuring Mothering," 79.

${ }^{110}$ Present-day textbooks, magazines and websites do often, at least nominally, include fathers, but fathers are generally lauded for simply taking part, for giving support. Mothers are expected to take most of the responsibility, and so all the blame is also theirs. 